\title{
Temporal patterns of foraging activities of northern gannets, Morus bassanus, in the northwest Atlantic Ocean
}

\author{
Stefan Garthe, Silvano Benvenuti, and William A. Montevecchi
}

\begin{abstract}
We investigated time allocation and diel rhythms in foraging northern gannets (Morus bassanus). Chick-rearing adults on Funk Island, Newfoundland, Canada, were equipped with different types of data loggers. We found no effects of the devices on the birds' behaviour or breeding success. A total of 25 foraging trips were recorded from 16 birds.

Foraging-trip durations (median $13.5 \mathrm{~h}$, range 3.0-39.2 h) showed a bimodal distribution, coinciding with a partitioning of foraging trips into 1- and 2-day trips. Some individuals were consistent in performing either 1- or 2-day trips. During foraging trips, gannets were flying, on average, $44 \%$ of the time. Foraging activities exhibited a clear diel rhythm. Flight and diving activity was concentrated during early morning and late afternoon, with reduced activity during midday. Gannets were inactive at night. Flight time between the terminal dive of a foraging trip and arrival at the colony was significantly longer during 2-day trips $(94 \pm 22 \mathrm{~min}$; mean $\pm \mathrm{SD}$ ) than during 1-day trips $(51 \pm 22 \mathrm{~min})$. Water masses visited differed between 1- and 2-day trips. We could find no evidence for a clear dual foraging strategy, although birds were exploiting more distant waters during 2-day trips, as has been found for many procellariform species.
\end{abstract}

\begin{abstract}
Résumé : Nous avons examiné l'emploi du temps et le rythme quotidien de recherche de nourriture chez le foude-bassan (Morus bassanus). Des adultes éleveurs de poussins sur l'île Funk, Terre-Neuve, Canada, ont été munis de différents types d'appareils enregistreurs de données. Nous n'avons constaté aucun effet de ces appareils sur le comportement ou sur le succès de la reproduction des oiseaux. Au total, 25 excursions de quête de nourriture ont été observées mettant en cause 16 oiseaux. La durée des excursions (médiane 13,5 h, étendue 3,0-39,2 h) suivait une courbe bimodale, correspondant au partitionnement des excursions en épisodes de 1 et 2 jours. Certains des oiseaux faisaient toujours des excursions de la même durée, soit 1 ou 2 jours. Au cours de leurs excursions de quête de nourriture, les oiseaux volaient en moyenne $44 \%$ du temps. L'activité de quête de nourriture se faisait selon un rythme circadien bien défini. Les oiseaux concentraient leurs activités de vol et de plongée au petit matin et en fin d'après-midi et étaient moins actifs au milieu de la journée. Les oiseaux étaient inactifs la nuit. La durée du vol entre la plongée finale d'une excursion de quête de nourriture et l'arrivée à la colonie était significativement plus longue au cours des excursions de 2 jours $(94 \pm 22 \mathrm{~min}$; moyenne \pm écart type) qu'au cours de celles de 1 jour $(51 \pm 22 \mathrm{~min})$. Les masses d'eau visitées différaient selon que les excursions duraient 1 ou 2 jours. Même si les oiseaux visitaient des eaux plus distantes au cours d'excursions de 2 jours, nous n'avons pas trouvé de preuves d'une stratégie double bien définie de quête de nourriture, comme c'est le cas chez de nombreuses espèces d'oiseaux marins procellariformes.
\end{abstract}

[Traduit par la Rédaction]

\section{Introduction}

During chick rearing, seabirds are constrained in their foraging options for obtaining food for both themselves and their offspring (Orians and Pearson 1979). The resolution of potential conflicts determines the outcome of longer term life-history trade-offs between provisioning oneself and one's offspring (Roff 1992; Stearns 1992; McNamara and Houston 1996). These conflicts are most evident among pelagic species that live year-round on the high seas, a highly variable environment. One foraging solution for meeting the needs of both adults and offspring is the strategy of performing a mixture of long and short foraging trips (Weimerskirch et al. 1994). During short trips parents target foraging areas near the colony and tend to lose body mass while gathering food for chicks. In contrast, during long trips they exploit foraging areas as far as several hundred kilometres away and tend to gain body mass while collecting sufficient food for both their own requirements and those of their offspring (Weimerskirch et al. 1997).

Received 15 March 2002. Accepted 14 January 2003. Published on the NRC Research Press Web site at http://cjz.nrc.ca on 9 April 2003.

S. Garthe. ${ }^{1}$ Research and Technology Centre, University of Kiel, Hafentörn, D-25761 Büsum, Germany.

S. Benvenuti. Dipartimento di Etologia, Ecologia ed Evoluzione, University of Pisa, Via A. Volta 6, I-56126 Pisa, Italy.

W.A. Montevecchi. Departments of Psychology and Biology, Memorial University of Newfoundland, St. John's, NL A1B 3X9, Canada.

${ }^{1}$ Corresponding author (e-mail: garthe@ftz-west.uni-kiel.de). 
However, not all seabirds perform long, wide-ranging foraging trips and many do not exhibit a bimodal distribution of foraging-trip durations. For example, the northern gannet (Morus bassanus), a pelecaniform species, engages in much shorter foraging trips than most procellariform species (Nelson 1978; Hamer et al. 1997, 2000; Garthe et al. 1999). For example, Hamer et al. (2000) found foraging-trip durations of 13-84 h (mean $32 \mathrm{~h}$ ) for northern gannets breeding at Bass Rock in the North Sea. Nelson (1978) calculated average chick-guarding spells (<7-week-old chicks, similar to our study) of $19 \mathrm{~h}$ at Bass Rock and $20 \mathrm{~h}$ at Ailsa Craig. Garthe et al. (1999) measured durations of 3-27 h (mean $13 \mathrm{~h}$ ) at a colony in Shetland, and even shorter chick-guarding spells, averaging $7 \mathrm{~h}$, were recorded at Bempton in northeastern England (Nelson 1978). Lewis et al. (2001) found evidence that foraging-trip duration is related to colony size and thus possibly to intraspecific competition for prey.

It is not known if northern gannets use a dual foraging strategy or whether foraging trips are similar in length and structure. In the closely related Cape gannet (Morus capensis), Adams and Klages (1999) found a bimodal distribution of foraging-trip durations.

It is important to know how foraging trips are structured in order to understand foraging decisions made by seabirds. Do gannets employ a general strategy that underlies different foraging tactics? Is food taken at specific times during trips? How is time allocated to different activities? We used different data-logging units attached to breeding northern gannets in eastern Canada to assess the characteristics of foraging trips. It is essential to address these types of questions in order to better understand how seabirds respond to fluctuations in prey availability and hence to assess the mechanisms and limitations of using seabird performance as an indicator of prey conditions (Montevecchi 1993).

\section{Methods}

\section{Date and location}

This study was carried out between 26 July and 5 August 1999 at the northern gannet colony consisting of about 9800 pairs (Chardine 2000) on Funk Island $\left(49^{\circ} 45^{\prime} \mathrm{N}, 53^{\circ} 11^{\prime} \mathrm{W}\right)$, a flat $800 \times 400 \mathrm{~m}$ granite rock located about $50 \mathrm{~km}$ off the northeast coast of Newfoundland, Canada, in the northwest Atlantic Ocean. Additional observational data were gathered between 30 July and 7 August 2001 at the same site.

\section{Capture of birds}

Adult northern gannets with 4- to 5-week-old chicks, caught with a telescoping noose-pole from within a portable blind to reduce disturbance to neighbouring birds, were equipped with miniaturized data-logging units. Recaptures took place the same way. Nests at the periphery of the colony were chosen in order not to disturb major parts of the colony. We cannot exclude the possibility that birds breeding in the centre of a colony differ from those at the periphery, so to reduce this potential bias, we selected birds breeding in the third or fourth row from the periphery. Breeding success was high at the sites where we worked. Capture took usually 2-3 min and processing the birds (attaching devices, marking the bird) lasted 5-10 min at the maximum. All birds were cared for in accordance with the principles and guidelines of the Canadian Council on Animal Care.

\section{Devices used}

We used three different types of loggers to study the foraging behaviour of northern gannets. Twenty-two adults were equipped with data loggers; data were obtained from 16 birds that were recaptured. Durations of attachment varied from 27 to $75 \mathrm{~h}$. All birds were marked on the head and neck with coloured magic markers for identification from a distance and banded with U.S. Fish and Wildlife Service (USFWS) bands issued by the Canadian Wildlife Service.

\section{LTD loggers}

LTD_100 tags (light-temperature-depth recorders; Lotek Marine Technologies, St. John's, Newfoundland, Canada) were used to derive dive depth (from a pressure sensor) and diving activity (in water, in air, or on land from a temperature sensor). They were $57 \mathrm{~mm}$ long with a diameter of $18 \mathrm{~mm}$ and a mass of $16 \mathrm{~g}$; memory size was $1 \mathrm{MB}$. Devices were attached by Tesa ${ }^{\circledR}$ tape to two plastic bands placed on one leg of each bird. Pressure was recorded every $2 \mathrm{~s}$ over a depth range of $0-100 \mathrm{~m}$ with a resolution of $0.04 \mathrm{~m}$. External temperature was recorded every $30 \mathrm{~s}$. The activity of the bird could be deduced from records of thermal fluctuations (following Wilson et al. 1995; Garthe et al. 1999). When the temperature remained constant, the bird was considered to be swimming or resting on the water surface with the logger submerged and indicating sea-surface temperature (SST). When the recorded temperature varied slightly within the range recorded for air temperature (a few degrees higher than SST), the bird was considered to be flying. When the temperature varied in higher ranges (as the logger was warmed by the bird's and chick's body heat and often by solar and terrestrial radiation) and with other daily rhythms, the bird was considered to be in the colony (i.e., at the nest for most of the time). The last deduction was validated by observations made with a spotting scope from outside the colony to check when marked birds carrying loggers were present; the former deductions were corroborated using information derived from other devices described below.

\section{Onset loggers}

Onset loggers (Onset Computer Corporation, Pocasset, Massachusetts, U.S.A.) were used to derive activity from an external temperature sensor. The devices $(17 \times 31 \times 41 \mathrm{~mm}$, $20 \mathrm{~g}$ ) had a memory of approximately $8 \mathrm{kB}$ and were attached by Tesa $^{\circledR}$ tape to two plastic bands placed on one leg of each marked bird. Temperature was measured every $60 \mathrm{~s}$, from which activity was derived as indicated above.

\section{DAR loggers}

DAR loggers (Dall'Antonia Recorders, Istituto di Elaborazione dell'Informazione, Italian Research Council (C.N.R.), Pisa, Italy) were used to indicate diving depth (from a pressure sensor) and activity (from a motion sensor). These devices (80 $\mathrm{mm}$ long, 22-31 $\mathrm{mm}$ wide, $13-18.5 \mathrm{~mm}$ high, $28 \mathrm{~g}$ ) had a memory capacity of $128 \mathrm{kB}$. These loggers are modified versions of those used in previous experiments on homing pigeons and marine birds (see Dall'Antonia et al. 1993, 1995; Benvenuti et al. 1998). They contain a depth 
Fig. 1. Durations of 25 foraging trips made by 16 telemetered northern gannets, Morus bassanus, from Funk Island.

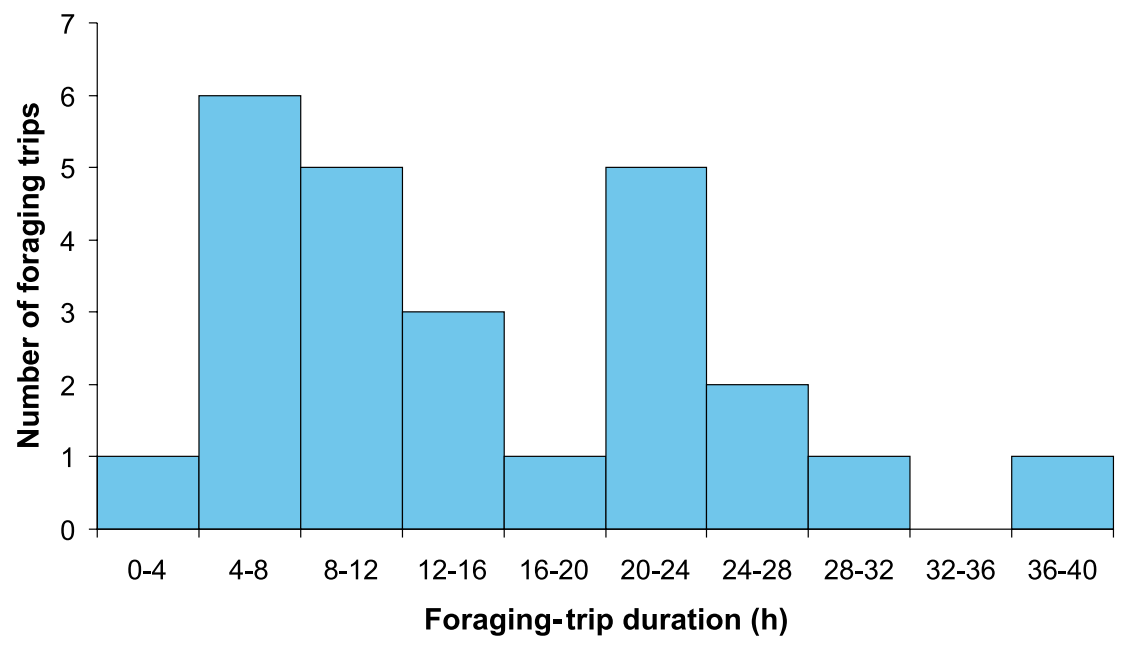

meter with an operative range of $0-70 \mathrm{~m}$ and a resolution of $0.3 \mathrm{~m}$ and a flight sensor that differentiates flight from activities at the nest and at sea. The flight or motion sensor is a $5 \mathrm{~mm}$ diameter modified microphone, the membrane of which is activated by accelerations generated by body movements. During flight, the signals are produced by accelerations and (or) body vibrations caused by wing beats. During diving, signals are produced by wing and (or) foot movements. Time intervals between successive recordings were $4 \mathrm{~s}$ for depth meters and $6 \mathrm{~s}$ for flight sensors. These devices were attached with Tesa ${ }^{\circledR}$ tape to either feathers on the lower back about $5 \mathrm{~cm}$ above the uropygial gland or the four central tail feathers.

After deployment, the pressure and temperature devices were recalibrated in the field at institutes in Kiel and Pisa.

\section{Hydrographic measurements}

Temperature measurements from the LTD and Onset loggers appeared to have stabilized sufficiently after a maximum of $3 \mathrm{~min}$, so a minimum swimming time of 3 min was considered necessary for analyses of SST. In addition to these SST measurements obtained during all swimming periods of at least $3 \mathrm{~min}$, SST could also be assessed at many dives. Sometimes the birds' swimming time before or after dives was not sufficient for accurate measurements to be obtained. However, SST could be assigned to 150 out of 214 dives $(70 \%)$ during which birds carried LTD loggers with both temperature and pressure sensors. Unlike temperature sensors, pressure sensors react immediately, so dive depths were always known precisely.

\section{Observations in the colony}

To collect more data on foraging-trip durations, in 2001 we conducted frequent spotting-scope scans of multiple consecutive foraging trips by different individuals equipped with different data loggers; these are not reported in this study. Data collected during scans were used to determine whether the birds returned on the day that they departed or on the following day. Marked birds and their partners were studied. Data are presented for 24 individuals belonging to 12 pairs for which at least three consecutive trips of one partner were recorded.

\section{Analyses of data}

No more than three foraging trips were recorded per individual, so data from all 16 birds were pooled, as bias due to individual characteristics should have been negligible. For Student's $t$ tests we only used one trip per individual, selected randomly, when data from more than one trip were available.

Analyses of diel rhythms in flying, swimming, and diving are based only on recordings made during the time the birds were at sea.

\section{Results}

\section{Foraging-trip duration and timing}

Foraging-trip durations in 1999 showed a bimodal distribution with peaks at intervals of 4-8 and 20-24 h (Fig. 1). These peaks coincided with a separation of foraging trips into 1- and 2-day trips. The shortest trip recorded lasted $3.0 \mathrm{~h}$, the longest lasted $39.2 \mathrm{~h}$, and the median was $13.5 \mathrm{~h}$ $(n=25)$. The longest trip extended over 2 nights. Most foraging trips were initiated during the morning and relatively few in the afternoon (Fig. 2). The later the bird started during the day, the higher the probability that it would return to the nest the following day. However, when the day was split in two halves (departure before or after 1200), the differences were not significant $\left(\chi^{2}=2.49\right.$, ns, $\left.n=25\right)$. Furthermore, foraging-trip duration was not significantly correlated with time of departure from the colony $\left(r_{\mathrm{S}}=0.072, p=\right.$ $0.734, n=25$ ).

According to the additional data from 2001, some pairs showed consistency in conducting either 1- or 2-day trips, but many individuals showed no consistency in foraging-trip duration (Table 1).

\section{Water masses visited during foraging trips}

Based on SST, northern gannets from Funk Island on 1and 2-day foraging trips visited water masses in significantly different proportions $\left(\chi^{2}=28.73\right.$, df $\left.=6, p<0.001\right)$. Gannets at sea for 1 day most frequently visited waters with SST of $14.1-15.0^{\circ} \mathrm{C}$, though there was no such clear tendency in birds that had been at sea for 2 consecutive days (Fig. 3). 
Fig. 2. Timing of the start of 1-day $(n=12)$ and 2-day $(n=12)$ foraging trips by 15 northern gannets from Funk Island. Note that the single 2-night trip is not included here.

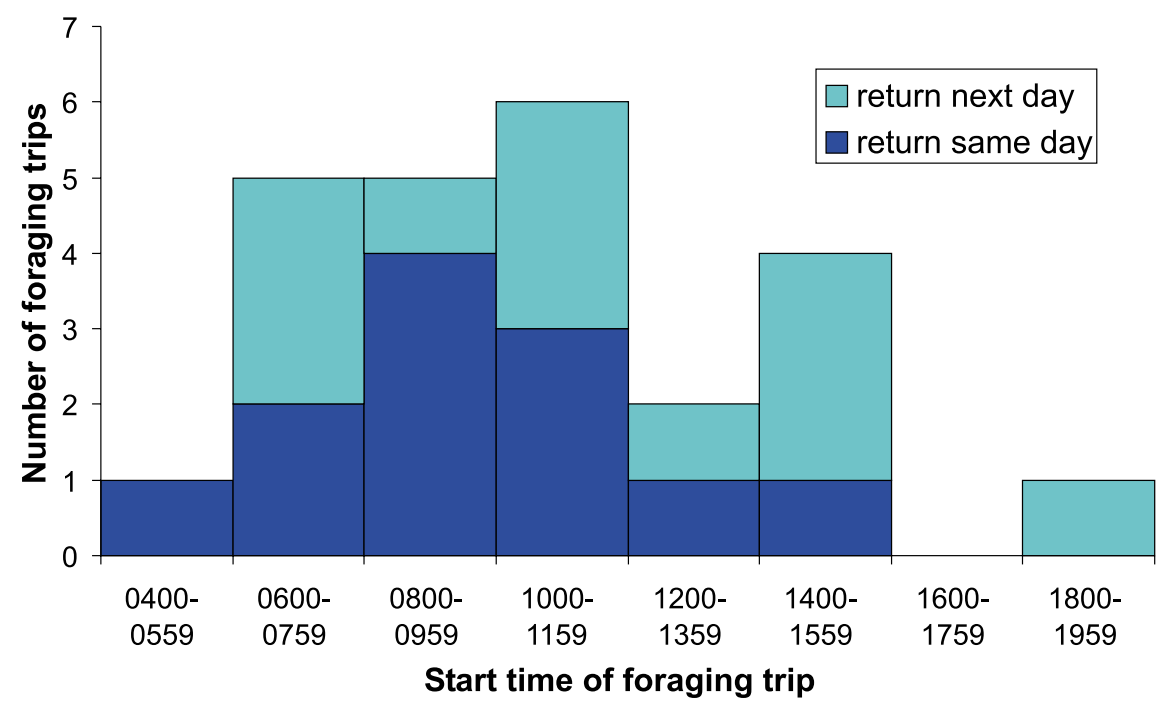

Table 1. Sequence of durations (days) of foraging trips by telemetered northern gannets, Morus bassanus, from Funk Island that were watched for three or more foraging trips in 2001, and by their respective mates.

\begin{tabular}{|c|c|c|c|c|c|c|c|}
\hline Bird ID No. & 1st trip & 2nd trip & 3rd trip & 4th trip & 5th trip & 6th trip & 7th trip \\
\hline 1 & 2 & 2 & 2 & 2 & 2 & 2 & \\
\hline 2 (mate of 1$)$ & 1 & 1 & 1 & 1 & 1 & 1 & \\
\hline 3 & 2 & 1 & 2 & 1 & 1 & & \\
\hline Mate of 3 & 2 & 2 & 2 & 2 & & & \\
\hline 4 & 2 & 2 & 2 & 2 & 2 & 2 & \\
\hline Mate of 4 & 1 & 1 & 1 & 1 & 1 & 1 & \\
\hline 5 & 2 & 2 & 2 & 2 & 2 & 1 & 1 \\
\hline Mate of 5 & 1 & 1 & 1 & 1 & 1 & 2 & 2 \\
\hline 6 & 2 & 2 & 2 & 1 & 1 & 1 & \\
\hline Mate of 6 & 1 & 1 & 2 & 2 & 2 & $?$ & \\
\hline 7 & 2 & 1 & 1 & 1 & 2 & 2 & \\
\hline Mate of 7 & 1 & 1 & 2 & 1 & 1 & 1 & \\
\hline 8 & 2 & 1 & 1 & 1 & 2 & 1 & 1 \\
\hline Mate of 8 & 1 & 2 & 2 & 1 & 1 & 2 & \\
\hline 9 & 1 & 1 & 1 & 1 & 1 & & \\
\hline Mate of 9 & 2 & 2 & 2 & 2 & & & \\
\hline 10 & 1 & 2 & 1 & 1 & 1 & & \\
\hline Mate of 10 & 1 & 2 & 2 & 2 & 2 & & \\
\hline 11 & 1 & 1 & 1 & 1 & 2 & 1 & \\
\hline Mate of 11 & 2 & $?$ & 1 & 2 & 1 & & \\
\hline 12 & 1 & 1 & 1 & & & & \\
\hline Mate of 12 & 2 & 1 & & & & & \\
\hline 13 & 1 & 1 & 1 & & & & \\
\hline Mate of 13 & 2 & 0 & & & & & \\
\hline
\end{tabular}

Waters with SST below $12.6^{\circ} \mathrm{C}$ were visited solely by birds on 2-day foraging trips.

\section{Activity allocation during foraging trips}

While at sea, northern gannets were flying, on average,
$44.2 \%$ (range $24.6-86.6 \% ; n=25$ foraging trips by 16 birds) of the time and were swimming for the other $55.8 \%$, on average (range 13.4-75.4\%). Flight activity showed considerable variation during the foraging trips (Fig. 4). During 1-day trips, the mean flight-activity level was high at the beginning and 
Fig. 3. Sea surface temperatures measured by LTD and temperature loggers attached to swimming northern gannets from Funk Island during 1-day ( $n=48$ measurements from four birds) and 2-day foraging trips ( $n=168$ measurements from seven birds).

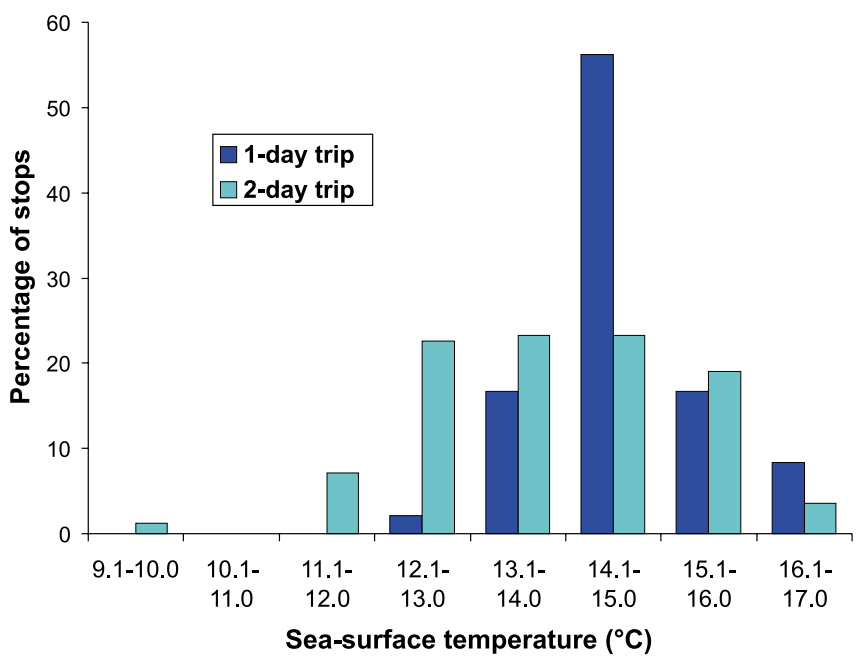

end of the trip and relatively low in between, when there was much diving behaviour (see below). During 2-day foraging trips, flight activity was more constant over both days, and no periods of strongly reduced mean flight activity were observed (Fig. 4). Flight activity was essentially nil at night (see below).

The proportion of time spent flying showed no significant relationships to the total foraging-trip duration (excluding the night during which no foraging occurred; Garthe et al. 2000; see below) $(r=-0.001, n=25, p=0.995)$. The same held true when 1-day trips $(r=-0.308, n=12, p=0.331)$ and 2-day trips $(r=-0.417, n=12, p=0.178)$ were considered separately. Thus, the proportion of time spent flying or swimming is not a function of foraging-trip duration.

\section{Timing of feeding during foraging trips}

There was no significant relationship between the frequency of dives that were only executed during daylight (Garthe et al. 2000) and diurnal foraging-trip duration $(r=$ $-0.36, n=25, p=0.188$ ). Diving activity showed distinct patterns over the course of foraging trips (Fig. 5). During 1day foraging trips, most dives occurred around the middle of the trip, with hardly any diving at the beginning or end. During 2-day foraging trips, diving was most pronounced during the latter half of the first day and the first half of the second day. These periods of intense diving were interspersed by the nocturnal rest. Time allocation also varied in absolute values between 1 - and 2-day trips. Flight time between colony departure and first dive did not differ between 1-day trips $(89 \pm 17$ min (mean $\pm \mathrm{SD}), n=5)$ and 2-day trips $(81 \pm$ $19 \min , n=6 ; t=0.755$, df $=9, p=0.470$ ), though there was a much longer flight period between the terminal dive of a foraging trip and arrival at the colony during 2-day trips (94 $\pm 22 \mathrm{~min}, n=5)$ than during 1-day trips $(51 \pm 22 \mathrm{~min}$, $n=6 ; t=-3.218$, df $=9, p=0.011$ ).

\section{Diel rhythm in foraging activities}

Irrespective of trip duration, foraging activities exhibited a clear diel rhythm. At night, gannets rarely flew, and then just for a few minutes. Flying activity was most frequent during morning between 0400 and 0900 and later in the day between 1300 and 1900 (Fig. 6). There was a midday period of strongly reduced flight activity. The diel rhythm in diving showed the same pattern, with the highest activity levels early in the morning and late in the day (Fig. 7). The earliest dive observed among all birds and foraging trips was executed at 0408 and the latest at 2005; the local photoperiod extended from about 0430 to about 2030 .

\section{Discussion}

\section{Possible effects of devices on the birds}

As reported by previous authors who employed the same activity loggers to investigate the foraging and diving behaviour of northern gannets in Shetland and on Funk Island (Garthe et al. 1999, 2000), no negative effects of the devices on the birds were detected. This assumption is based, firstly, on the high level of recaptures of birds with attached devices. Six recapture failures occurred: two were due to a too-early departure of the researchers because of weather problems (the birds were still at sea), one device fell off at sea, and two failures occurred because of chick losses due to nest fights and subsequent loss of the nest bond of the adults, so we could not recapture them; in one case the failure to recapture the bird was unexplained. Secondly, the same dive depths were obtained from different types of devices that were completely independent of each other and attached to three different parts of the bird's body; furthermore, some birds carried stomach thermal sensors and some did not (Garthe et al. 2000). Thirdly, all birds equipped simultaneously with stomach temperature loggers fed successfully during all trips (unpublished data; see Wilson et al. 1992; Garthe et al. 1999).

\section{Time allocation and diel rhythm during foraging trips}

Irregular alternation between short and long foraging trips has been found in some procellariform species, among which a long trip usually follows 2-5 short trips (Weimerskirch et al. 1994). In contrast to most procellariform species, northern gannets from Funk Island showed no indication that they alternated between short and long foraging trips. The bimodal distribution of foraging-trip durations can be attributed to a nocturnal break in foraging rather than to the tactic of alternating short and long foraging trips. However, some gannets on 2-day foraging trips did visit colder water masses, and gannets might actually use these longer trips to target such different water masses.

Despite similar overall behaviour of birds on 1- and 2-day foraging trips, there were differences in the allocation of activities during these trips. Diving is clearly separated into two main phases during 2-day trips: in the evening of the first day and the morning of the second. Between the two phases, a nocturnal rest period of many hours without flight activity is imposed. It is likely that food obtained on the first day is digested at night before the birds start to feed on the second day (cf. Hilton et al. 1998). Also, heat created by digesting food could be used to balance heat loss due to thermostatic costs while swimming on cold water (e.g., Croll and McLaren 1993). If, however, the night period is excluded, it 
Fig. 4. Proportions of flight activity during different (relative) parts of 1-day foraging trips, day 1 of 2-day trips, and day 2 of 2-day trips. Departure from the colony or the start of activity in the morning (for day 2 in 2-day trips) is indicated by $0 \%$ and arrival at the colony or cessation of activity in the evening (for day 1 of 2-day trips) by $100 \%$. The columns show mean percentages over the twelve 1-day and twelve 2-day foraging trips made by 15 northern gannets.

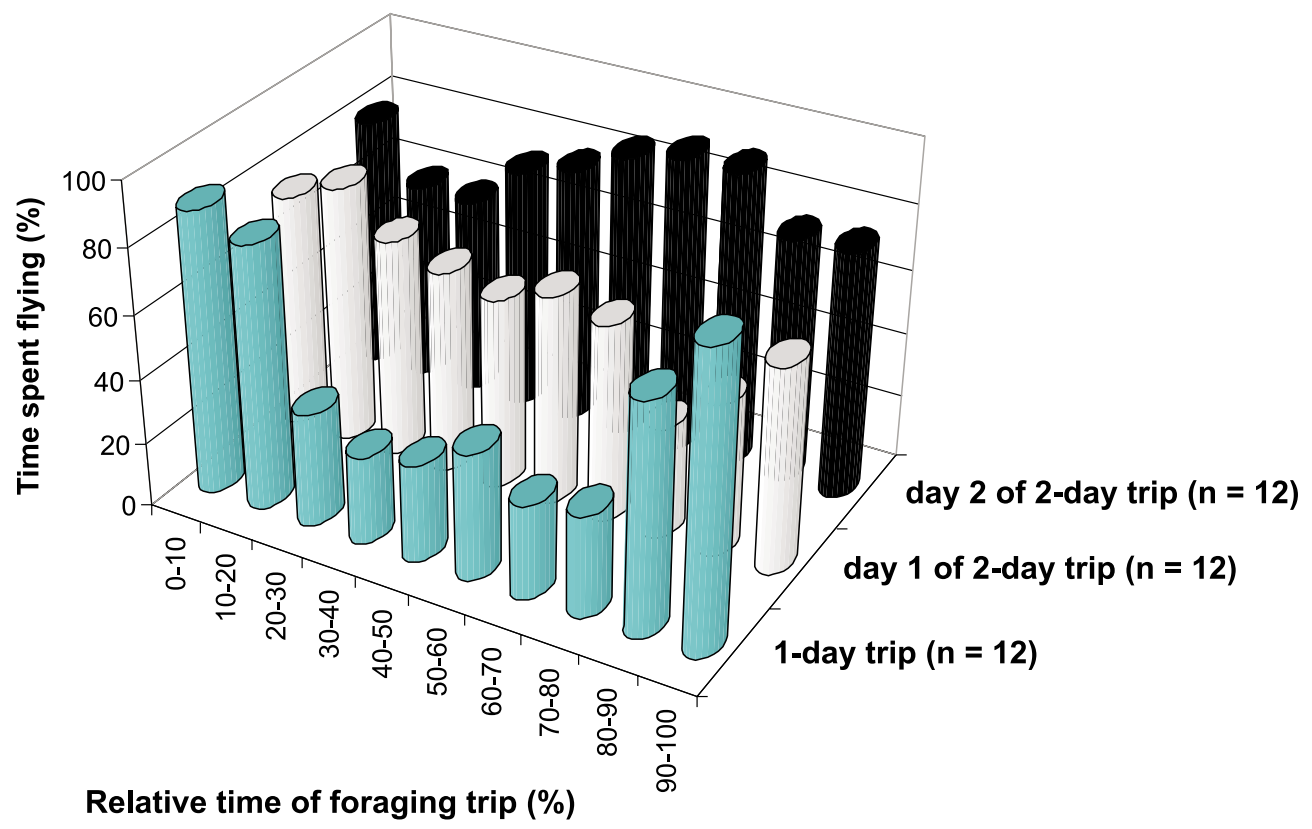

Fig. 5. Relative time spent diving during 1-day foraging trips, day 1 of 2-day trips, and day 2 of 2-day trips. Departure from the colony or the start of activity in the morning (for day 2 of 2-day trips) is indicated by $0 \%$ and arrival in the colony or cessation of activity in the evening (for day 1 of 2-day trips) by $100 \%$. The columns show mean percentages for eight 1-day and six 2-day foraging trips made by 10 northern gannets.

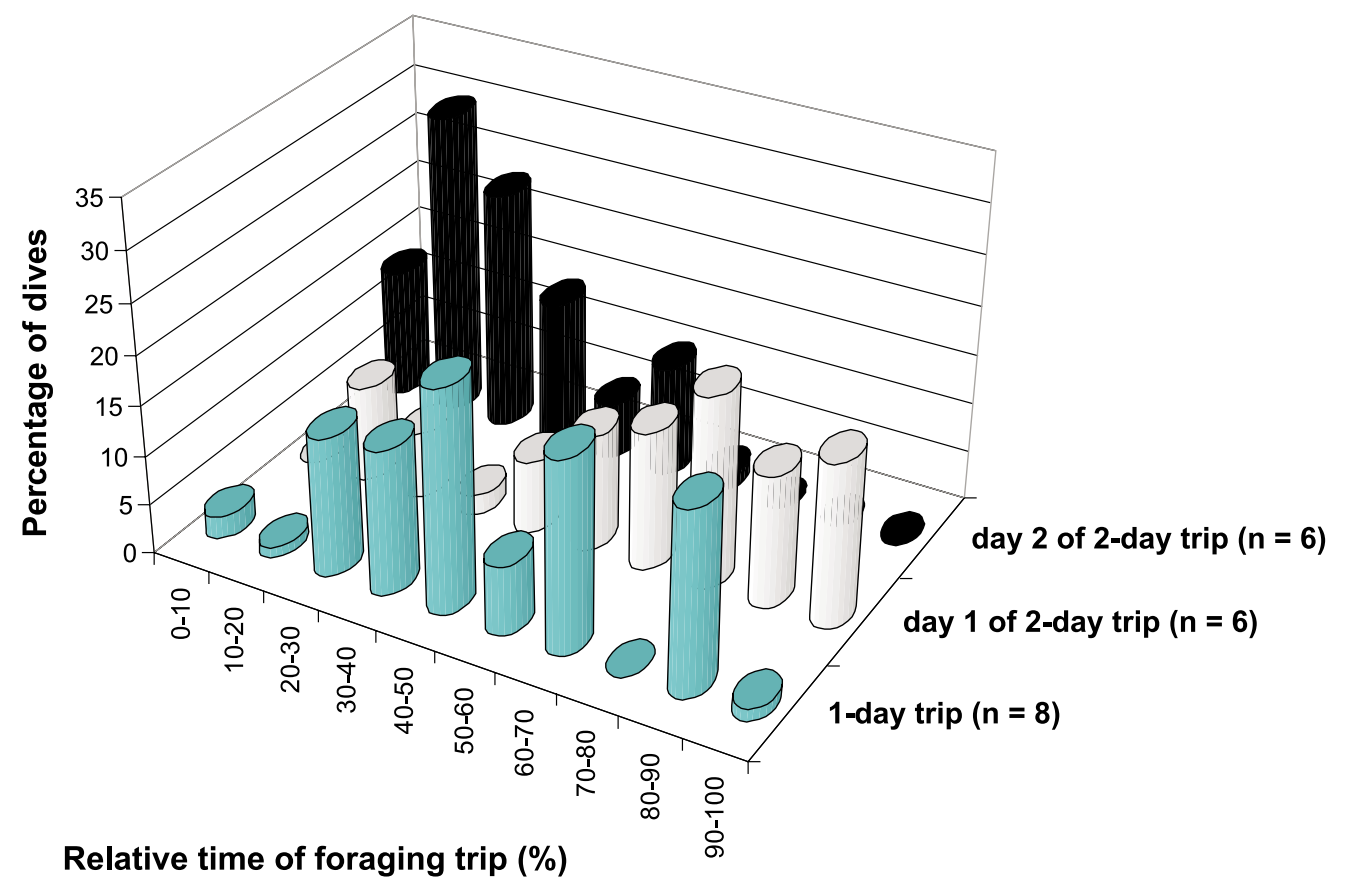

becomes obvious that during both types of foraging trip, diving is performed most often in the middle and much less often at the beginning and end of trips, therefore they resemble each other quite strongly.

Incomplete determinations of sex among telemetered birds do not allow for thorough investigations of sex-specific dif- ferences in foraging behaviour or trip durations (Lewis et al. 2002). However, from the birds that could be sexed and from some data obtained from the mates of equipped birds it is clear that foraging-trip type cannot be allocated easily to either sex. Nevertheless, sex-specific foraging patterns have been found in northern gannets (Lewis et al. 2002), northern 
Fig. 6. Diel rhythm in the percentage of time at sea that was spent flying (the remainder (up to 100\%) was spent swimming). Values are given as means \pm SD for each first foraging trip recorded for 11 northern gannets on Funk Island in 1999. The numbers immediately below the $x$ axis are sample sizes.

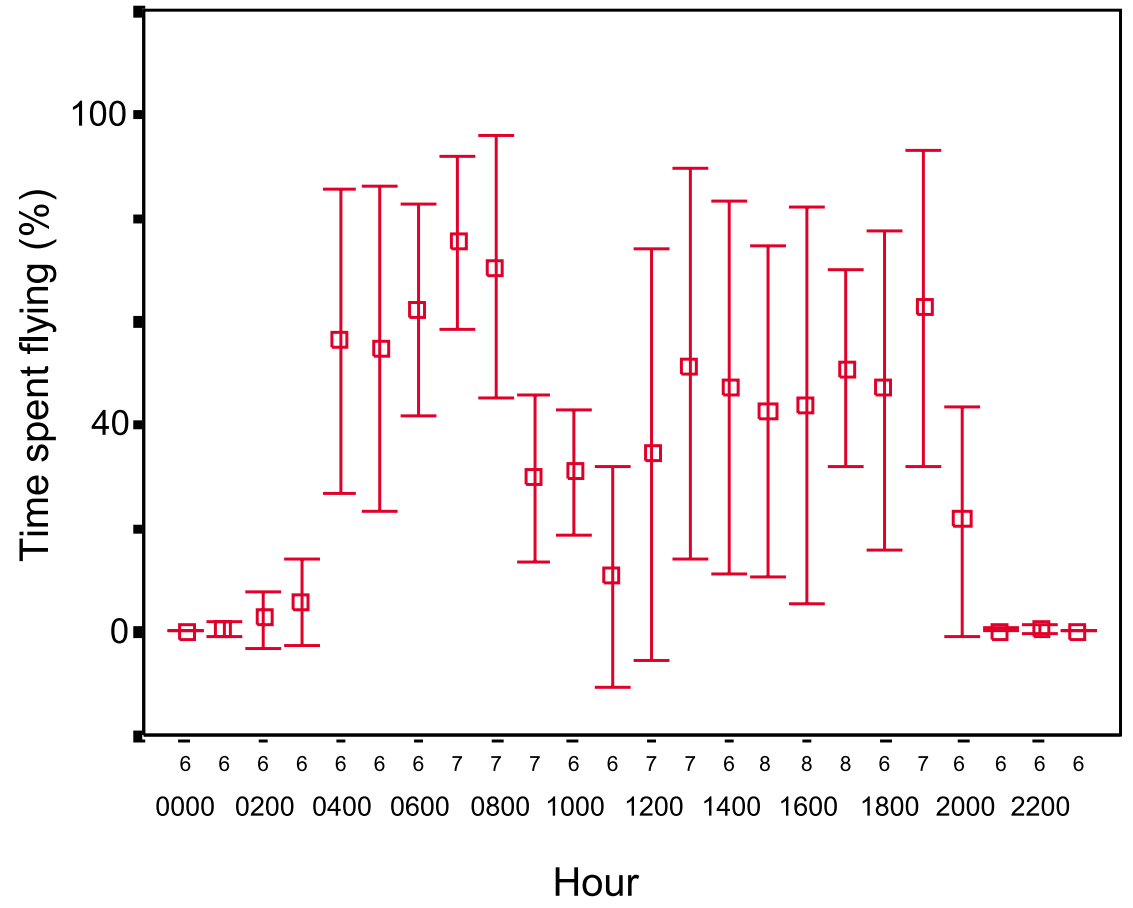

Fig. 7. Diel rhythm in diving activity, expressed as the number of dives per hour at sea. Values are given as means \pm SD for each first foraging trip recorded for 11 northern gannets on Funk Island in 1999. The numbers immediately below the $x$ axis are sample sizes.

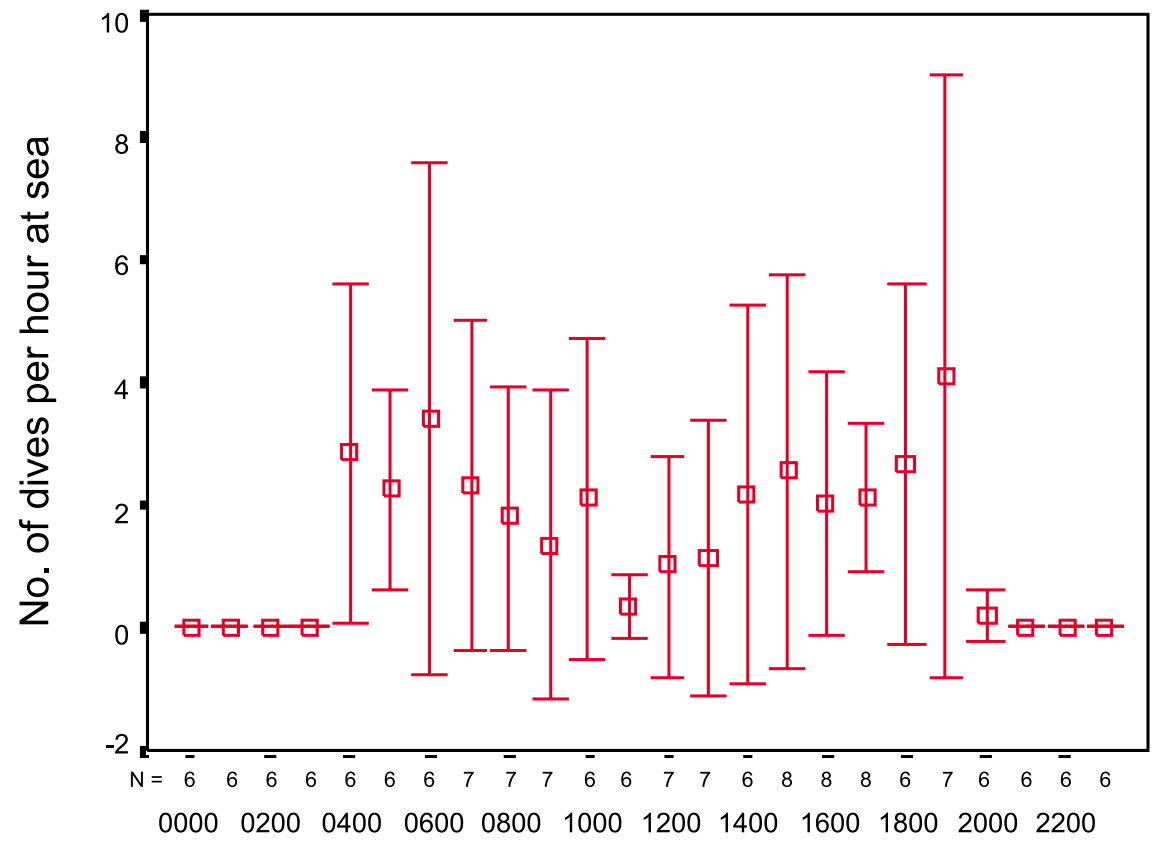

Hour

giant petrels (Macronectes halli; González-Solís et al. 2000), and other seabirds. Even more obviously, chick age could not be responsible for differences in the observed foraging patterns because chick ages were largely the same among all pairs studied.

Two-day trips may prove advantageous over 1-day trips because the food ingested on the first day could be digested overnight. One might speculate that adults feed themselves on the first day and then load food for chicks on the second day (cf. Peters 1997a, 1997b). One-day trips should serve for both self-feeding and chick-provisioning more or less at the same time by providing a higher feeding rate to the 
chick than 2-day trips do. More temporal flexibility within the longer foraging trips could be beneficial if foraging birds select or explore better sites for feeding. Such tactics could reduce the rate at which chicks are provisioned with food, owing to longer absences from the nest, although provisioning with high-quality food obtained on longer trips could offset the costs of longer between-feeding intervals. Many individual mates appear to exhibit complementary patterns of 1- and 2-day trips. However, trip durations are not independent among mates, and mates could constrain each other.

\section{Conclusions}

We described and analysed temporal aspects of foraging trips made by breeding northern gannets. We found that gannets engaged in 1- and 2-day foraging trips and that some birds on longer trips foraged in colder waters. Longer trips provided foraging birds with more behavioural flexibility. This allowed birds on 2-day foraging trips to fly to more distant areas, as was shown by some birds foraging in colder water and also by the significantly longer flight period after the terminal dive of a trip (likely a dive for food for offspring). Increased time could also be used to explore new sites or to search longer or more intensively for prey. A distinct diel rhythm underlies activities at sea, and gannets are constrained by the period of darkness, unlike most procellariform species (e.g., McNeil et al. 1993).

\section{Acknowledgements}

This study was a cooperative German-Canadian-Italian project supported by grants from the Deutsche Forschungsgemeinschaft (Ga 617/1; to S.G.), the Natural Sciences and Engineering Research Council of Canada (to W.A.M.), and the C.N.R. (to S.B.). Further support came from the Institut für Meereskunde in Kiel (D. Adelung), the University of Pisa, and Memorial University of Newfoundland. The Newfoundland and Labrador Parks Division permitted us to work in the Funk Island Ecological Seabird Reserve. Gail Davoren assisted during fieldwork. Luigi Dall'Antonia allowed us to use his DAR loggers, Rory Wilson provided Onset temperature loggers. Alberto Ribolini, Istituto di Elaborazione dell'Informazione, C.N.R., Pisa, developed the software applied in part of the primary data analysis for the DAR loggers. John Hillier from Lotek Marine Technologies in St. John's, Newfoundland, provided technical support. We are grateful to all of them.

\section{References}

Adams, N.J., and Klages, N.T.W. 1999. Foraging effort and prey choice in Cape gannets. S. Afr. J. Mar. Sci. 21: 157-163.

Benvenuti, S., Bonadonna, F., Dall'Antonia, L., and Gudmundsson, G.A. 1998. Foraging flights of breeding thick-billed murres (Uria lomvia) as revealed by bird-borne direction recorders. Auk, 115: 57-66.

Chardine, J.W. 2000. Census of northern gannet colonies in the Atlantic Region in 1999. Canadian Wildlife Service, Atlantic Region, Sackville, N.B. Tech. Rep. Ser. No. 361.

Croll, D.A., and McLaren, E. 1993. Diving metabolism and thermoregulation in common and thick-billed murres. J. Comp. Physiol. B, 163: $160-166$.
Dall'Antonia, P., Dall'Antonia, L., and Ribolini, A. 1993. Flight path reconstruction of birds by a route recorder. In Biotelemetry XII: Proceedings of the XII International Symposium on Biotelemetry, Ancona, Italy, 31 Aug. - 5 Sept. 1992. Edited by P. Mancini, S. Fioretti, C. Cristalli, and B. Bedini. Litografia Felici, Pisa, Italy. pp. 544-549.

Dall'Antonia, L., Dall'Antonia, P., Benvenuti, S., Ioalè, P., Massa, B., and Bonadonna, F. 1995. The homing behaviour of Cory's shearwaters (Calonectris diomedea) studied by means of a direction recorder. J. Exp. Biol. 198: 359-362.

Garthe, S., Grémillet, D., and Furness, R.W. 1999. At-sea-activity and foraging efficiency in chick-rearing northern gannets (Sula bassana): a case study in Shetland. Mar. Ecol. Prog. Ser. 185: 93-99.

Garthe, S., Benvenuti, S., and Montevecchi, W.A. 2000. Pursuitplunging by northern gannets (Sula bassana) feeding on capelin (Mallotus villosus). Proc. R. Soc. Lond. B Biol. Sci. 267: 17171722.

González-Solís, J., Croxall, J.P., and Wood, A.G. 2000. Sexual dimorphism and sexual segregation in foraging strategies of Northern Giant Petrels, Macronectes halli, during incubation. Oikos, 90: 390-398.

Hamer, K.C., Thompson, D.R., and Gray, C.M. 1997. Spatial variation in the feeding ecology, foraging ranges, and breeding energetics of northern fulmars in the north-east Atlantic Ocean. ICES J. Mar. Sci. 54: 645-653.

Hamer, K.C., Phillips, R.A., Wanless, S., Harris, M.P., and Wood, A.G. 2000. Foraging ranges, diets and feeding locations of gannets Morus bassanus in the North Sea: evidence from satellite telemetry. Mar. Ecol. Prog. Ser. 200: 257-264.

Hilton, G.M., Houston, D.C., and Furness, R.W. 1998. Which components of diet quality affect retention time of digesta in seabirds? Funct. Ecol. 12: 929-939.

Lewis, S., Sherratt, T.N., Hamer, K.C., and Wanless, S. 2001. Evidence of intra-specific competition for food in a pelagic seabird. Nature (Lond.), 412: 816-819.

Lewis, S., Benvenuti, S., Dall'Antonia, L., Griffiths, R., Money, L., Sherratt, T.N., Wanless, S., and Hamer, K.C. 2002. Sex-specific foraging behaviour in a monomorphic seabird. Proc. R. Soc. Lond. B Biol. Sci. 269: 1687-1693.

McNamara, J.M., and Houston, A.I. 1996. State-dependent life histories. Nature (Lond.), 380: 215-221.

McNeil, R., Drapeau, P., and Pierotti, R. 1993. Nocturnality in colonial waterbirds: occurrence, special adaptations, and suspected benefits. Curr. Ornithol. 10: 187-246.

Montevecchi, W.A. 1993. Birds as indicators of change in marine prey stocks. In Birds as monitors of environmental change. Edited by R.W. Furness and J.J.D. Greenwood. Chapman \& Hall, London. pp. 217-266.

Nelson, J.B. 1978. The gannet. Poyser, Berkhamsted, U.K.

Orians, G.H., and Pearson, N.E. 1979. On the theory of central place foraging. In Analysis of ecological systems. Edited by D.J. Horn, R.D. Mitchell, and G.R. Stairs. Ohio State University Press, Columbus. pp. 155-177.

Peters, G. 1997a. A new device for monitoring gastric $\mathrm{pH}$ in freeranging animals. Am. J. Physiol. 273: G748-G753.

Peters, G. 1997b. Die Regulation der Verdauungsvorgänge bei Pinguinen (Spheniscidae). Ph.D. thesis, University of Kiel, Kiel, Germany.

Roff, D.A. 1992. The evolution of life histories: theory and analysis. Chapman \& Hall, New York.

Stearns, S.C. 1992. The evolution of life histories. Oxford University Press, Oxford. 
Weimerskirch, H., Chastel, O., Chaurand, T., Ackerman, L., Hindermeyer, X., and Judas, J. 1994. Alternate long and short foraging trips in pelagic seabird parents. Anim. Behav. 47: 472-476.

Weimerskirch, H., Cherel, Y., Cuenot-Chaillet, F., and Ridoux, V. 1997. Alternative foraging strategies and resource allocation by male and female wandering albatrosses. Ecology, 78: 20512063.
Wilson, R.P., Cooper, J., and Plötz, J. 1992. Can we determine when marine endotherms feed? A case study with seabirds. J. Exp. Biol. 167: 267-275.

Wilson, R.P., Weimerskirch, H., and Lys, P. 1995. A device for measuring seabird activity at sea. J. Avian Biol. 26: 172-175. 